\title{
COOKIES TEPUNG BERAS HITAM DAN KEDELAI HITAM SEBAGAI ALTERNATIF MAKANAN SELINGAN INDEKS GLIKEMIK RENDAH
}

\author{
Ayu Widiawati A, Gemala Anjani*) \\ ${ }^{*}$ Program Studi Ilmu Gizi Fakultas Kedokteran Universitas Diponegoro \\ Jln. Prof. H. Soedarto, SH., Semarang, Telp (024) 8453708, Email : gizifk@ undip.ac.id
}

\begin{abstract}
Background: Diabetes Mellitus is a disease due to metabolic abnormalities which is the prevalence has been increasing each year. Patients with diabetes mellitus type 2 need snacks to help fulfilling their nutrient-needs and control their blood's glucose level. The black rice and black soybean flour cookies are expected to have a low glycemic index so it can be used as an alternative snack for DM type II patients.

Purpose: To analyze protein, fat, carbohydrate, fiber content, glycemic index, and glycemic load of black rice and black soybean flour cookies.

Method: This study used a completely randomized experimental design with one factor, that is the formulation of black soybean flours are $0 \%, 15 \%, 25 \%$, and $35 \%$. Nutrient-content's data was analyzed by One Way Anova test continued with Tukey test, while the preference level was analyzed by Friedman test. Glycemic index determined with IAUC method.

Result: Black rice and black soybean flour cookies had a significant effect on protein, fat, carbohydrate, and fiber content. the most accepted is the formulation of $65 \%$ blak rice flour and $35 \%$ balck soybean flour. The glycemic index and glycemic load of cookies with formulated of $65 \%$ black rice flour 35\% black soybean flour are 39,74 and 4,75. The organoleptic tests of black rice and black soybean flour cookies shows that low on taste acceptance level that is 2,34.

Summary: Black rice and black soybean flour cookies results protein, fat, carbohydrate, and fiber content are significantly different. The acceptance level of black rice and black soybean flour cookies is low on taste. The black rice and black soybean flour cookies has a low glycemic index and glycemic load those are 39,74 and 4,75.
\end{abstract}

Keywords: Cookies, black rice flour, black soybean flour, nutrient content, glycemic index, glycemic load.

\section{ABSTRAK}

Latar Belakang: Diabetes mellitus merupakan penyakit karena kelainan metabolik yang jumlah penderitanya mengalami peningkatan tiap tahun. Penderita Diabetes Melitus tipe II membutuhkan makanan selingan untuk mencukupi kebutuhan gizi serta mengontrol kadar glukosa darah. Cookies tepung beras hitam dan kedelai hitam diharapkan memiliki indeks glikemik yang rendah sehingga dapat dijadikan alternatif makanan selingan penderita DM tipe II.

Tujuan: Menganalisis kandungan protein, lemak, karbohidrat, serat, indeks glikemik, dan beban glikemik cookies tepung beras hitam dan tepung kedelai hitam.

Metode : Penelitian eksperimental acak lengkap satu faktor yaitu formulasi tepung kedelai hitam sebesar $0 \%, 15 \%, 25 \%$, dan 35\%. Data kandungan zat gizi dianalisis menggunakan uji One Way Anova, dilanjutkan dengan Uji Tukey, sedangkan analisis tingkat penerimaan menggunakan Uji Friedman. Nilai indeks glikemik ditentukan menggunakan metode IUAC. Hasil : Tepung kedelai hitam berpengaruh nyata terhadap kadar protein, lemak, karbohidrat, dan serat. Nilai indeks glikemik dan beban glikemik dari cookies dengan formulasi 65\% tepung beras hitam dan 35\% kedelai hitam yaitu 39,74 dan 4,75. Uji organoleptik cookies tepung beras hitam dan kedelai hitam rendah pada tingkat penerimaan rasa yaitu sebesar 2,34.

Simpulan : Cookies tepung beras hitam dan kedelai hitam memberikan hasil kadar protein,lemak, karbohidrat, dan serat yang berbeda secara bermakna. Tingkat penerimaan cookies tepung beras hitam dan kedelai hitam rendah pada kategori rasa. Cookies tepung beras hitam dan kedelai hitam memiliki indeks glikemik dan beban glikemik yang rendah yaitu sebesar 39,74 dan 4,75.

Kata kunci : Cookies, tepung beras hitam, tepung kedelai hitam, kandungan gizi, indeks glikemik, beban glikemik

\section{PENDAHULUAN}

Diabetes melitus (DM) merupakan kelainan metabolik yang mempengaruhi metabolisme karbohidrat, lemak, dan protein. ${ }^{1}$ Jumlah penderita DM di dunia mengalami peningkatan dari tahun ke tahun. ${ }^{2}$ Menurut International Federation Diabetes, sejumlah 382 juta orang dewasa diseluruh dunia atau $8,3 \%$ mengalami diabetes. $80 \%$ diantaranya tinggal dalam negara berpendapatan rendah dan menengah. Apabila tren tersebut berlanjut, sekitar tahun 2035 sejumlah 592 juta orang atau satu dari sepuluh orang dewasa akan mengalami diabetes. ${ }^{3}$ Indonesia menduduki peringkat sepuluh besar sebagai negara dengan penderita diabetes tertinggi di dunia, di bawah negara kawasan Eropa, Amerika, dan China. Penderita DM di Indonesia semakin meningkat, dimana sebesar 90\% - 95\% merupakan DM tipe 2 . Diperkirakan pada tahun 2030 penderita DM di Indonesia mengalami kenaikan, sehingga penderita diabetes di Indonesia berjumlah 21,3 juta orang. ${ }^{4}$ 
Diabetes Melitus yang paling sering dijumpai pada orang dewasa adalah Diabetes Melitus tipe 2.5 Diabetes Melitus tipe 2 disebabkan oleh resistensi insulin akibat kegagalan kerja pankreas dalam mengkompensasi tingginya gula darah. Salah satu faktor peningkatan kejadian DM tipe 2 yaitu asupan makanan yang tidak seimbang. Asupan makanan tinggi lemak, gula, dan rendah serat berhubungan dengan peningkatan kadar glukosa darah postprandial. Pengendalian kadar glukosa darah dapat dilakukan melalui pengaturan pola makan. Strategi dalam pengaturan pola makan yang dapat dilakukan untuk membantu mengendalikan kadar glukosa darah salah satunya melalui konsumsi makanan dengan indeks glikemik (IG) rendah. Penelitian menunjukkan makanan IG rendah mampu memperbaiki sensitivitas insulin serta menurunkan laju penyerapan glukosa, sehingga bermanfaat dalam pengendalian glukosa darah penderita DM. ${ }^{6}$

Penderita DM selain membutuhkan makanan utama, juga membutuhkan makanan selingan untuk mengendalikan kadar glukosa darah. ${ }^{7}$ Waktu memberikan makanan selingan adalah diantara dua waktu makan utama, tepatnya diantara waktu makan pagi dan makan siang, serta diantara makan siang dan makan malam. Bahan makanan yang digunakan untuk membuat makanan selingan mengandung padat zat gizi, tinggi serat, dan IG rendah sehingga selain mencukupi kebutuhan zat gizi, juga diharapkan tidak menyebabkan hiperglikemia. Selain itu, makanan selingan juga berfungsi untuk mencegah hipoglikemia yang biasa terjadi pada malam hari. Konsumsi makanan dengan IG rendah dapat mengakibatkan kadar glukosa darah cenderung stabil karena glukosa diserap secara perlahan sehingga tidak menimbulkan penurunan glukosa darah secara drastis.

Beras merupakan bahan makanan sumber energi yang memiliki kandungan karbohidrat tinggi namun proteinnya rendah. Beras putih merupakan bahan makanan pokok sebagian besar masyarakat Indonesia. Salah satu bahan makanan yang dapat digunakan sebagai pengganti beras putih adalah beras hitam. Indeks glikemik beras hitam tergolong rendah yaitu sebesar 42,3. Salah satu faktor penyebabnya adalah kandungan serat beras hitam yang lebih tinggi. ${ }^{8}$ Pada penderita diabetes serat larut berfungsi menangkap karbohidrat dan memperlambat proses penyerapan glukosa sehingga menurunkan kadar glukosa dalam darah.

Beras hitam memiliki kandungan protein sebesar $8 \%$, lemak 1,3\%, karbohirat $76,9 \%$, dan serat $20,1 \%$. Kandungan protein beras hitam cukup rendah sehingga untuk meningkatkan kadar protein dapat dilakukan dengan mengkombinasikan dengan bahan dari kacang-kacangan seperti kacang kedelai hitam. Kacang kedelai hitam umumnya dimanfaatkan sebagai bahan baku pembuatan kecap. Kedelai hitam merupakan sumber protein nabati dengan kandungan protein $35-40 \%$ dan bernilai IG rendah yakni $31.9,10$ Pemanfaatan beras hitam dan kedelai hitam dalam pembuatan makanan dapat bermanfaat karena kandungan gizi keduanya saling melengkapi.

Bentuk olahan sederhana dari beras hitam dan kedelai hitam adalah pembuatan tepung. Olahan tepung dapat dibuat sebagai bahan baku produk. Cookies merupakan produk kering yang mempunyai daya awet yang tinggi sehingga dapat disimpan dalam waktu yang lama. Dalam tingkat penerimaan, panelis agak terlatih akan memberikan penilaian terhadap karakteristik cookies tepung beras hitam dan kedelai hitam, yang meliputi warna, aroma, rasa, tekstur, dan penilaian terhadap cookies secara keseluruhan. Dengan mengetahui selera panelis agak terlatih terhadap beberapa formula cookies tepung beras hitam dan kedelai hitam, diharapkan produk ini dapat dikembangkan lebih luas bagi masyarakat umum.

\section{METODE}

Penelitian yang dilakukan termasuk dalam bidang keilmuan Ilmu Teknologi Pangan yang dilaksanakan pada bulan Agustus - November 2016. Proses produksi dan pengujian kandungan gizi cookies dilaksanakan di Laboratorium Terpadu Universitas Diponegoro Semarang. Pengujian nilai indeks glikemik cookies dilakukan di Kampus Program Studi Ilmu Gizi Universitas Diponegoro Semarang. Selain itu, dilakukan juga pengujian tingkat penerimaan produk terhadap 25 panelis agak terlatih yang dilakukan di Kampus Program Studi Ilmu Gizi Universitas Diponegoro.

Penelitian ini merupakan penelitian dengan rancangan acak lengkap satu faktor, yaitu empat variasi kadar tepung beras hitam dan tepung kedelai hitam. Masing - masing kelompok dilakukan pengulangan sebanyak 3 kali. Berikut ini formulasi cookies tepung beras hitam dan tepung kedelai hitam berdasarkan penelitian terdahulu yang terkait. ${ }^{24}$

Tabel 1. Formulasi Tepung Beras Hitam dan Kedelai Hitam pada Cookies.

\begin{tabular}{ccc}
\hline Perlakuan & Tepung Beras Hitam (\%) & Tepung Kedelai Hitam (\%) \\
\hline $\mathrm{B}_{100}$ & 100 & 0 \\
$\mathrm{~B}_{85} \mathrm{~K}_{15}$ & 85 & 15 \\
$\mathrm{~B}_{75} \mathrm{~K}_{25}$ & 75 & 25 \\
$\mathrm{~B}_{65} \mathrm{~K}_{35}$ & 65 & 35 \\
\hline
\end{tabular}


Bahan utama pembuatan cookies adalah tepung beras hitam dan tepung kedelai hitam. Tepung beras hitam yang digunakan bermerk Gasol yang didapatkan dari penjual Tepung Organik Gasol di Kota Semarang, sedangkan kedelai hitam yang digunakan didapatkan di Pasar Peterongan Kota Semarang, Jawa Tengah. Tepung kedelai hitam dibuat sendiri oleh peneliti. Pembuatan tepung kedelai hitam dilakukan dengan merendam kedelai hitam yang sudah bersih selama 2 jam, setelah 2 jam kedelai dipisahkan dari air rendaman kemudian dikeringkan dalam oven dengan suhu $50^{\circ} \mathrm{C}$ selama 8 jam. Kedelai hitam yang sduah dioven dihaluskan menggunakan grinder, kemudian diayak menggunakan ayakan..$^{25}$ Bahan lain yang digunakan dalam pembuatan cookies antara lain adalah $50 \mathrm{~g}$ telur; $25 \mathrm{~g}$ margarin; $1,5 \mathrm{~g}$ gula stevia; $0,5 \mathrm{~g}$ garam; $0,2 \mathrm{~g}$ baking soda; dan $0,5 \mathrm{~g}$ vanili yang didapatkan di toko bahan kue di Kota Semarang. Proses pembuatan cookies diawali dengan menghomogenkan margarin, telur, dan gula selama 2 - 3 menit, kemudian memasukkan bahan lainnya hingga tercampur rata. Selanjutnya adonan dicetak dan dipanggang dengan suhu $150^{\circ} \mathrm{C}$ selama $20-25$ menit.

Data yang dikumpulkan dalam penelitian ini adalah data kandungan gizi, nilai IG, dan tingkat penerimaan cookies tepung beras hitam dan kedelai hitam. Cookies tepung beras hitam dan kedelai hitam dengan empat formulasi yang berbeda diuji kandungan lemak, serat kasar, air, dan abu dengan metode SNI 01-2891-1992, sedangkan dilakukan pengujian dengan metode Bradford untuk kandungan protein. Uji tingkat penerimaan yang dilakukan oleh panelis agak terlatih sebanyak 25 orang mahasiswa Program Studi Ilmu Gizi Universitas Diponegoro meliputi warna, aroma, tekstur, dan rasa. Tingkat penerimaan cookies menggunakan uji hedonik dengan 5 skala, yaitu $1=$ sangat tidak suka, $2=$ tidak suka, $3=$ netral, $4=$ suka, $5=$ sangat suka. Nilai rerata yang diperoleh kemudian dikategorikan, antara lain $\leq 1,4$ termasuk sangat tidak suka, 1,5 - 2,4 termasuk tidak suka, 2,5 - 3,4 termasuk netral, 3,5 - 4,4 termasuk suka, dan 4,5 - 5 termasuk sangat suka. Data tingkat penerimaan diuji statistik dengan menggunakan uji Friedman karena data berdistribusi tidak normal, dilanjutkan dengan uji Wilcoxon untuk mengetahui beda nyata antar kelompok perlakuan dan kontrol.

Pada pengujian nilai IG data yang dikumpulkan adalah nilai indeks glikemik cookies tepung beras hitam dan kedelai hitam dari cookies dengan formulasi terbaik berdasarkan tingkat penerimaan dari 25 panelis. Karbohidrat available diperoleh dari perhitungan by difference. Perhitungan IG menggunakan metode incremental area under the blood glucose response curve (IAUC). Pengujian IG menggunakan subjek sebanyak 10 orang dengan kriteria inklusi dan eksklusi. Kriteria inklusi subjek antara lain adalah memiliki status gizi normal dengan IMT $18,5-22,9 \mathrm{~kg} / \mathrm{m}^{2}$ dan GDP $<100 \mathrm{mg} / \mathrm{dl}$, serta dalam rentang usia dewasa yaitu 18-30 tahun. Kriteria eksklusi subjek antara lain sakit serta mengonsumsi obat-obatan selama intervensi. Salah satu subjek drop out, tidak bisa mengikuti penelitian hingga akhir sehingga jumlah subjek adalah 9 orang. Subjek diminta berpuasa (kecuali air putih) selama 10 jam pada malam sebelum penelitian, kemudian diukur kadar glukosa darah puasa pagi harinya. Selanjutnya subjek diminta mengkonsumsi pangan acuan (glukosa murni) dan pangan uji yang setara dengan 50 gram karbohidrat available. Glukosa murni diberikan sebanyak 50 gram dalam bentuk bubuk, kemudian dilarutkan ke dalam air sebanyak $250 \mathrm{ml}$. Setiap perlakuan dilakukan pada 9 orang yang sama dan diberi jarak 3-5 hari untuk menghindari bias dari makanan yang diujikan. Sampel darah subjek diambil setiap 30 menit $(30,60,90$, dan 120 menit) sebanyak 1-2 $\mu \mathrm{L}$. Pengukuran glukosa darah subjek menggunakan glukometer merk GlucoDr, produksi All Medicus Co., Ltd. Data glukosa darah subjek kemudian ditebar pada sumbu $\mathrm{X}$ sebagai waktu (menit) dan sumbu Y sebagia kadar glukosa darah. Besarnya IG dihitung dengan membandingkan luas daerah di bawah kurva pangan uji (cookies tepung beras hitam dan kedelai hitam) dan pangan standar (glukosa murni), kemudian hasilnya dirata-rata. Indeks glikemik terbagi dalam tiga jenis yaitu IG rendah $(<55)$, sedang(55-70), dan tinggi $(>70)$. Luas kurva dihitung dengan rumus :

$\mathrm{L}=\frac{\Delta 30 t}{2}+\Delta 60 t+\frac{(\Delta 30-\Delta 60) t}{2}+\Delta 90 t+\frac{(\Delta 60-\Delta 90) t}{2}+\Delta 120 t+\frac{(\Delta 90-\Delta 120) t}{2}$

Keterangan

$\mathrm{L}=$ Luas area di bawah kurva

$\mathrm{t}=$ interval waktu pengambilan darah (30 menit)

$\Delta 30=$ selisih kadar glukosa darah 30 menit setelah beban dengan puasa

$\Delta 60=$ selisih kadar glukosa darah 60 menit setelah beban dengan puasa

$\Delta 90=$ selisih kadar glukosa darah 90 menit setelah beban dengan puasa

$\Delta 120=$ selisih kadar glukosa darah 120 menit setelah beban dengan puasa 


\section{HASIL}

\section{Kandungan Gizi}

Hasil analisis kandungan zat gizi dapat dilihat pada lampiran dan secara singkat dapat dilihat pada Tabel 2.

Data kandungan gizi berdistribusi normal sehingga dianalisis menggunakan uji One Way Anova, dilanjutkan uji Tukey dengan derajat kepercayaan 95\%. Cookies tepung beras hitam 100\% memiliki kandungan karbohidrat dan serat kasar tertinggi, dimana dalam $100 \mathrm{~g}$ terdapat karbohidrat sebesar 70,26g dan serat kasar 19,62g. Cookies tepung beras hitam $65 \%$ dan kedelai hitam 35\% memiliki kandungan lemak dan protein tertinggi dimana dalam $100 \mathrm{~g}$ terdapat lemak $30,15 \mathrm{~g}$ dan protein $0,46 \mathrm{~g}$. Cookies tepung beras hitam $65 \%$ dan kedelai hitam $35 \%$ juga memiliki kandungan abu dan air tertinggi yaitu sebesar 1,21\% untuk kandungan abu dan $3,73 \%$ untuk kandungan air.

Tabel 2. Rerata Kandungan Zat Gizi Per 100 g Cookies

\begin{tabular}{lcccccc}
\hline \multirow{2}{*}{ Perlakuan } & \multicolumn{7}{c}{ Kandungan Gizi } \\
\cline { 2 - 7 } & Karbohirat (\%) & Lemak (\%) & $\begin{array}{c}\text { Protein } \\
(\mathbf{\% )}\end{array}$ & Serat (\%) & Abu (\%) & Air (\%) \\
\hline $\mathbf{B}_{\mathbf{1 0 0}}$ & $70,26 \pm 0.13$ & $25,55 \pm 0.22$ & $0,27 \pm 0,02$ & $19,62 \pm 0,80$ & $0,99 \pm 0,01$ & $3,05 \pm 0,07$ \\
$\mathbf{B}_{\mathbf{8 5}} \mathbf{K}_{\mathbf{1 5}}$ & $69,33 \pm 0,25$ & $26,21 \pm 0,09$ & $0,28 \pm 0.02$ & $16,98 \pm 0,60$ & $1,01 \pm 0,12$ & $3,23 \pm 0,05$ \\
$\mathbf{B}_{\mathbf{7 5}} \mathbf{K}_{\mathbf{2 5}}$ & $66,67 \pm 0,12$ & $28,50 \pm 0,09$ & $0,36 \pm 0.04$ & $16,54 \pm 0,26$ & $1,13 \pm 0,08$ & $3,41 \pm 0,16$ \\
$\mathbf{B}_{\mathbf{6 5}} \mathbf{K}_{\mathbf{3 5}}$ & $64,37 \pm 0,09$ & $30,15 \pm 0,12$ & $0,46 \pm 0.10$ & $16,26 \pm 1,44$ & $1,21 \pm 0,14$ & $3,73 \pm 0,15$ \\
\hline & $\mathrm{p}=0,000$ & $\mathrm{p}=0,000$ & $\mathrm{p}=0,007$ & $\mathrm{p}=0,008$ & $\mathrm{p}=0,000$ & $\mathrm{p}=0,219$ \\
\hline
\end{tabular}

\section{Kadar Serat}

Hasil uji serat kasar cookies tepung beras hitam dan kedelai hitam sesuai pada Tabel 3 . menunjukkan bahwa kadar tertinggi terdapat pada cookies dengan perlakuan tepung beras hitam $100 \%$.
Semakin tinggi persentase subsitusi kedelai hitam semakin rendah kadar serat yang terkandung pada cookies. Hasil uji statistik menunjukkan bahwa subsitusi kedelai hitam menaikkan kadar serat secara bermakna $(p=0,008)$.

Tabel 3. Hasil Uji Serat Kasar Cookies Tepung Beras Hitam dan Kedelai Hitam

\begin{tabular}{lc}
\hline Perlakuan & Kadar Serat \\
\hline Tepung Beras Hitam 100\% & $19,62 \pm 0,80$ \\
Tepung Beras Hitam 85\%, Kedelai Hitam 15\% & $16,98 \pm 0,60$ \\
Tepung Beras Hitam 75\%, Kedelai Hitam 25\% & $16,54 \pm 0,27$ \\
Tepung Beras Hitam 65\%, Kedelai Hitam 35\% & $16,26 \pm 1,44$ \\
\hline & $\mathrm{p}=0,008$ \\
\hline
\end{tabular}

\section{Tingkat Penerimaan}

Hasil analisis tingkat penerimaan terhadap rasa, warna, aroma, dan tekstur pada Cookies Tepung Beras Hitam dan Kedelai Hitam adalah sebagai berikut.
Penentuan cookies terbaik untuk diuji indeks glikemik dipilih berdasarkan skor yang didapatkan. Dari keempat formulasi, cookies dengan 65\% tepung beras hitam dan 35\% kedelai hitam merupakan formulasi terbaik.

Tabel 4. Hasil Analisis Tingkat Kesukaan Cookies Tepung Beras Hitam dan Kedelai Hitam

\begin{tabular}{ccccccccc}
\hline \multirow{2}{*}{ Cookies } & \multicolumn{2}{c}{ Warna } & \multicolumn{2}{c}{ Aroma } & \multicolumn{2}{c}{ Tekstur } & \multicolumn{2}{c}{ Rasa } \\
\cline { 2 - 9 } & Rerata & Ket & Rerata & Ket & Rerata & Ket & Rerata & Ket \\
\hline \multirow{2}{*}{$\mathrm{B}_{100}$} & $3,24 \pm 1,13$ & Netral & $3,08 \pm 1,15$ & Netral & $2,60 \pm 0,95$ & Netral & $2,24 \pm 0,87$ & $\begin{array}{c}\text { Tidak } \\
\text { Suka }\end{array}$ \\
& & & & & & & & Tidak \\
$\mathrm{B}_{85} \mathrm{~K}_{15}$ & $3,04 \pm 0,61$ & Netral & $3,64 \pm 0,86$ & Suka & $2,68 \pm 0,62$ & Netral & $2,32 \pm 0,80$ & Suka \\
$\mathrm{B}_{75} \mathrm{~K}_{25}$ & $3,16 \pm 0,85$ & Netral & $3,04 \pm 0,84$ & Netral & $2,88 \pm 1,01$ & Netral & $2,12 \pm 0,66$ & Tidak \\
$\mathrm{B}_{65} \mathrm{~K}_{35}$ & $3,28 \pm 0,79$ & Netral & $3,60 \pm 1,0$ & Suka & $3,28 \pm 0,84$ & Netral & $2,68 \pm 0,98$ & Netral \\
\hline & $\mathrm{p}=0,378$ & & $\mathrm{p}=0,013$ & & $\mathrm{p}=0,047$ & & $\mathrm{p}=0,190$ &
\end{tabular}




\section{Warna}

Berdasarkan hasil analisis data dapat diketahui bahwa warna cookies dengan nilai rerata tertinggi adalah cookies dengan $100 \%$ tepung beras hitam $\left(\mathrm{B}_{100}\right)$. Sedangkan nilai rerata terendah dari kategori warna adalah cookies dengan formulasi $85 \%$ tepung beras hitam dan $15 \%$ kedelai hitam $\left(\mathrm{B}_{85} \mathrm{~K}_{15}\right)$. Uji statistik menunjukkan bahwa tidak terdapat pengaruh yang signifikan $(p=0,378)$ antar perlakuan. Semua warna cookies masuk ke dalam kategori yang sama, yaitu kategori netral.

Aroma

Hasil uji statistik menunjukkan bahwa terdapat pengaruh yang signifikan $(p=0,013)$ tepung kedelai hitam pada tingkat kesukaan terhadap aroma cookies. Cookies dengan formulasi $85 \%$ tepung beras hitam dan 15\% kedelai hitam memiliki tingkat kesukaan terhadap aroma tertinggi dengan nilai 3,64 $\pm 0,86$ (suka). Sedangkan nilai rerata terendah dari kategori aroma adalah cookies dengan formulasi $75 \%$ tepung beras hitam dan 25\% kedelai hitam dengan nilai $3,04 \pm 0,84$ (netral).

\section{Tekstur}

Tabel 4 menunjukkan bahwa tingkat kesukaan tekstur tertinggi pada cookies $\mathrm{B}_{65} \mathrm{~K}_{35}$ dengan nilai 3,24 $\pm 0,87$ (netral). Hasil uji statistik menunjukkan bahwa terdapat pengaruh yang signifikan $(p=0,047)$ antara formulasi tepung beras hitam dan kedelai hitam terhadap tekstur cookies. Berdasarkan hasil analisis semakin banyak tepung kedelai hitam, maka tingkat kesukaan terhadap tekstur semakin meningkat. Semua cookies masuk ke dalam kategori yang sama, yaitu kategori netral.

Rasa

Hasil analisis tingkat kesukaan terhadap rasa cookies tertinggi dengan nilai 2,68 $\pm 0,98$ (netral) yaitu cookies $\mathrm{B}_{65} \mathrm{~K}_{35}$ (Tabel 3) dengan formulasitepung beras hitam $65 \%$ dan kedelai hitam $35 \%$. Sedangkan nilai rerata terendah dari kategori rasa adalah cookies dengan formulasi $75 \%$ tepung beras hitam dan $25 \%$ kedelai hitam $\left(\mathrm{B}_{75} \mathrm{~K}_{25}\right)$. Hasil uji statistik menunjukkan bahwa tidak terdapat pengaruh yang signifikan $(\mathrm{p}=0,190)$ antar formulasi terhadap rasa cookies.

\section{Karakteristik Subjek}

Subjek terdiri dari 9 orang perempuan yang telah bersedia untuk berpartisipasi dalam penelitian dengan menandatangani informed consent. Karakteristik subjek penelitian dapat dilihat pada Tabel 5.

Tabel 5. Karakteristik Subjek Penelitian

\begin{tabular}{|c|c|c|c|c|c|}
\hline Subjek & $\begin{array}{c}\text { Umur } \\
\text { (tahun) }\end{array}$ & $\begin{array}{c}\text { Berat } \\
\text { Badan } \\
(\mathrm{kg}) \\
\end{array}$ & $\begin{array}{c}\text { Tinggi } \\
\text { Badan } \\
(\mathrm{cm}) \\
\end{array}$ & $\begin{array}{c}\text { Indeks } \\
\text { Massa } \\
\text { Tubuh } \\
\left(\mathbf{k g} / \mathbf{m}^{2}\right) \\
\end{array}$ & $\begin{array}{c}\text { Gula } \\
\text { Darah } \\
\text { Puasa } \\
(\mathrm{mg} / \mathrm{dl}) \\
\end{array}$ \\
\hline 1 & 21 & 42 & 149 & 18,92 & 96 \\
\hline 2 & 22 & 63,6 & 168 & 22,53 & 99 \\
\hline 3 & 22 & 61 & 164 & 22,68 & 90 \\
\hline 4 & 22 & 52 & 167 & 18,65 & 80 \\
\hline 5 & 22 & 48 & 157 & 19,47 & 78 \\
\hline 6 & 22 & 48 & 159 & 18,99 & 89 \\
\hline 7 & 22 & 45 & 155 & 18,73 & 82 \\
\hline 8 & 20 & 52,3 & 156,5 & 21,35 & 87 \\
\hline 9 & 20 & 46 & 142,2 & 22,75 & 89 \\
\hline $\begin{array}{c}\text { Rata- } \\
\text { rata }\end{array}$ & 21,44 & 50,87 & 124,3 & 20,45 & 87,78 \\
\hline
\end{tabular}

Berdasarkan Tabel 5. di atas diketahui bahwa subjek memenuhi kriteria inklusi dengan memiliki rerata umur 21,44 tahun, IMT $20,45 \mathrm{~kg} / \mathrm{m}^{2}$ dan GDP $87,78 \mathrm{mg} / \mathrm{dl}$.

\section{Penentuan Jumlah Pangan Uji}

Pengujian indeks glikemik terbagi dalam dua perlakuan, yaitu pemberian pangan acuan dan pemberian pangan uji. Masing-masing sampel makanan mengandung 50 gram karbohidrat available yang diketahui dengan cara menghitung kadar karbohidrat available sampel dengan metode by different. ${ }^{19}$ Bahan pangan acuan yang digunakan berupa bubuk glukosa murni sebanyak 50 gram yang dilarutkan dalam $250 \mathrm{ml}$ air. ${ }^{17}$ Bahan pangan uji berupa cookies tepung beras hitam $65 \%$ dan kedelai hitam $35 \%$. Jumlah bahan pangan uji yang diberikan kepada subjek dapat dilihat di Tabel 6 . 
Tabel 6. Kandungan Gizi Cookies Setara dengan 50 gram Karbohidrat Available

\begin{tabular}{lc}
\hline 65\% Tepung Beras Hitam, 35\% Tepung Kedelai HItam & Berat \\
\hline Protein (\%) & 0,46 \\
Lemak (\%) & 30,15 \\
Serat Kasar (\%) & 16,25 \\
Abu (\%) & 1,21 \\
Air (\%) & 3,73 \\
Karbohidrat total* (\%) & 64,36 \\
Karbohidrat available** (\%) & 48,11 \\
Berat Cookies*** (g) & 96,22 \\
\hline
\end{tabular}

Keterangan :

* Karbohidrat total ${ }^{18}=100-($ air + abu + protein+ lemak $)$

**Karbohidrat available ${ }^{18}=100-($ air + abu+ protein+ lemak+ serat $)$

$* * *$ Berat cookies $=\frac{50 \mathrm{gr}}{\text { karbohidrat available }} \times 100$

Berdasarkan Tabel 6. diketahui bahwa berdasarkan analisis by different dapat diperoleh kadar karbohidrat available cookies tepung beras hitam $65 \%$ dan kedelai hitam 35\% sebesar 48,11\%. Jumlah pangan uji yang harus diberikan kepada subjek yaitu 96,22g.

Kadar Glukosa
Rata-rata hasil glukosa darah subjek terhadap pemberian glukosa murni dan cookies dapat dilihat pada Gambar 1.

Berdasarkan Gambar 1. diketahui bahwa puncak kenaikan kadar gula darah terjadi pada menit ke-30 setelah makan dan menurun secara bertahap pada menit-menit selanjutnya.

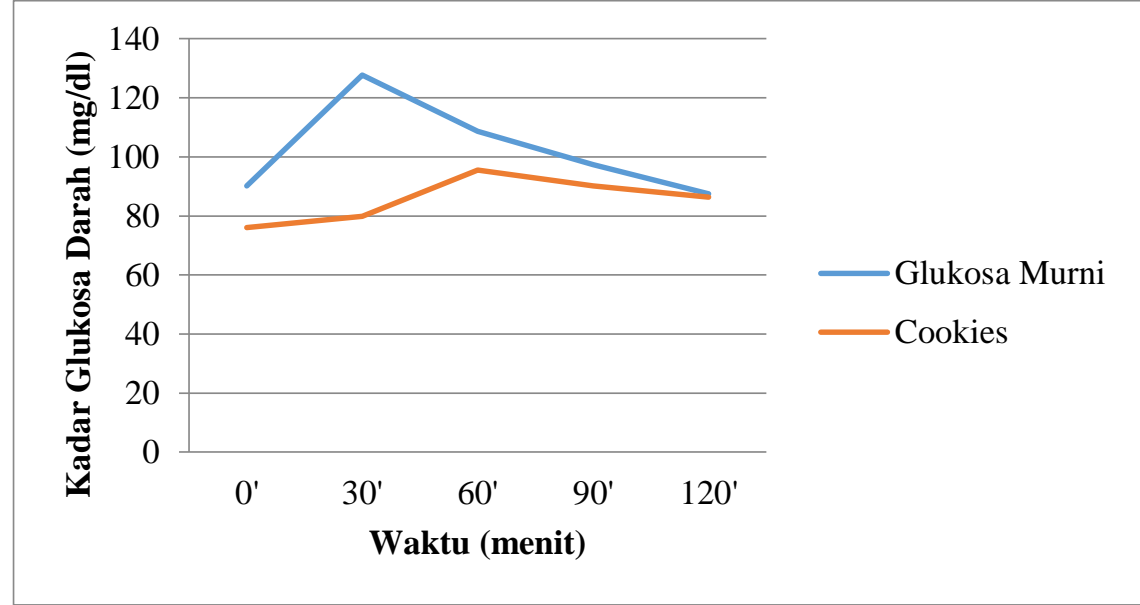

Gambar 1. Grafik Rata-rata Peningkatan Kadar Glukosa Darah

Tabel 7. Hasil Rata-rata Kadar Glukosa Darah (mg/dl)

\begin{tabular}{lccccc}
\hline \multicolumn{1}{c}{ Bahan Pangan } & \multicolumn{5}{c}{ Waktu (menit) } \\
& $\mathbf{0}$ & $\mathbf{3 0}$ & $\mathbf{6 0}$ & $\mathbf{9 0}$ & $\mathbf{1 2 0}$ \\
\hline Glukosa Murni & 90,2 & 127,67 & 108,67 & 97,33 & 87,44 \\
65\% Tepung Beras Hitam dan & 80,67 & 79,44 & 95,67 & 88,4 & 83,67 \\
35\% Tepung Kedelai Hitam & & & & \\
\hline
\end{tabular}

Berdasarkan Tabel 7, puncak peningkatan kadar gula darah tertinggi terdapat pada pemberian pangan acuan glukosa murni yaitu $127,67 \mathrm{mg} / \mathrm{dl}$ dan peningkatan glukosa darah terendah pada pemberian cookies tepung beras hitam dan 35\% tepung kedelai hitam yaitu sebesar 79,44 mg/dl.

Indeks Glikemik dan Beban Glikemik

Indeks glikemik cookies diperoleh dari hasil rata-rata IG 9 orang subjek. Hasilnya dapat dilihat pada Tabel 8 .

Berdasarkan Tabel 8, diketahui bahwa nilai indeks glikemik cookies tepung beras hitam dan tepung kedelai hitam dengan formulasi $65 \%$ tepung beras hitam dan 35\% tepung kedelai hitam termasuk ke dalam kategori rendah. Dengan nilai indeks glikemik sebesar $39,74 \%$. 


\begin{tabular}{cccc}
\multicolumn{4}{c}{ Tabel 8. Indeks Glikemik Cookies Tepung Beras Hitam dan Kedelai Hitam } \\
\hline $\begin{array}{c}\text { Cookies Tepung Beras Hitam } \\
\text { dan Kedelai Hitam }\end{array}$ & $\begin{array}{c}\text { Luas Area di } \\
\text { Bawah Kurva } \\
\left(\mathbf{c m}^{2}\right)\end{array}$ & $\begin{array}{c}\text { Indeks } \\
\text { Glikemik } \\
\mathbf{( \% )}\end{array}$ & Kategori * \\
\hline 65\% Tepung Beras Hitam dan & 11565 & 39,74 & Rendah \\
\hline * Kategori : IG repung Kedelai Hitam $(<55)$, sedang $(55-70)$, IG tinggi $(>70)^{18}$ & &
\end{tabular}

Tabel 9. Nilai Beban Glikemik Cookies Tepung Beras Hitam dan Kedelai Hitam

\begin{tabular}{|c|c|c|c|c|c|}
\hline Perlakuan & $\begin{array}{l}\text { Jumlah } \\
\text { Penyajian } \\
(\mathrm{g})^{21} \\
\end{array}$ & $\begin{array}{l}\text { Karbohidrat } \\
\text { Available } \\
(\%) \\
\end{array}$ & $\begin{array}{l}\text { Karbohidrat } \\
\text { Available /porsi } \\
(\%)^{*}\end{array}$ & $\begin{array}{c}\text { Beban } \\
\text { Glikemik** }\end{array}$ & Kategori*** \\
\hline $\begin{array}{l}\text { 65\% Tepung Beras } \\
\text { Hitam, 35\% Tepung } \\
\text { Kedai Hitam }\end{array}$ & 25 & 48 & 1203 & 475 & Rendah \\
\hline
\end{tabular}

Keterangan :

* Karbohidrat available $/$ porsi $^{19}=\frac{\text { jumlah penyajian }(\text { gram }) \times \text { karbohidrat available }}{100 \text { gram }}$

** $\quad \mathrm{BG}^{17}=\frac{I G x \text { jumlah karbohidrat available perporsi }}{100}$

*** Kategori : BG rendah $(<10)$, BG sedang (11-19), BG tinggi $(>20)^{18}$

Berdasarkan Tabel 9, diketahui bahwa nilai beban glikemik cookies dengan formulasi $65 \%$ tepung beras hitam dan 35\% tepung kedelai hitam termasuk ke dalam kategori rendah. Dengan nilai bebabn glikemik sebesar $4,75 \%$.

\section{PEMBAHASAN \\ Kandungan Zat Gizi}

Makanan selingan berfungsi untuk membantu mencukupi kebutuhan zat gizi dan mengontrol glukosa darah sebagai upaya mencegah risiko komplikasi pada penderita DM tipe $2{ }^{7}$ Kejadian hiperglikemia pada penderita diabetes mellitus dapat diatasi dengan pengendalian glukosa darah berupa pengaturan pola makan yang teratur. Pemberian diet seimbang cukup energi dan rendah indeks glikemik dengan 3 kali makan utama dan 2 kali makanan selingan dapat dilakukan untuk mengendalikan respon glikemik pada penderita diabetes mellitus. ${ }^{11}$

Total kebutuhan energi yang dianjurkan menurut rumus PERKENI pada penderita diabetes mellitus adalah $25 \mathrm{kalori} / \mathrm{kg}$ BB. ${ }^{12}$ Kandungan zat gizi per sajian makanan selingan umumnya sebesar 10 $15 \%$ dari total kebutuan kalori harian dan dapat dikonsumsi sebanyak 2-3 kali sehari, sehingga total kalori per sajian makanan selingan penderita diabetes mellitus adalah $200 \mathrm{kkal}$. Porsi penyajian cookies menurut Powell adalah sebesar 25 gram. ${ }^{13}$ Cookies yang dikembangkan bagi penderita DM salah satunya diformulasikan untuk membantu mencegah hiperglikemia dengan menggunakan bahan baku IG rendah dan tinggi serat.

Perhitungan kebutuhan karbohidrat yang dianjurkan bagi penderita DM tipe 2 adalah 55\% dari kebutuhan kalori harian, sehingga diperoleh kebutuhan karbohidrat makanan selingan per satu takaran saji sebanyak 27,5 g. Kandungan karbohidrat dalam satu takaran saji cookies tepung beras hitam $65 \%$ sebesar $16,09 \mathrm{~g} ; 75 \%$ beras hitam sebesar $16,67 \mathrm{~g} ; 85 \%$ beras hitam sebesar 17,33g; dan $100 \%$ beras hitam sebesar 17,56g. Pemenuhan asupan kabohidrat dalam satu takaran saji cookies tepung beras hitam $65 \%$ sebesar $58,51 \%, 75 \%$ beras hitam sebesar $60,61 \%, 85 \%$ beras hitam sebesar $63 \%$, dan $100 \%$ beras hitam sebesar $63,85 \%$.

Perhitungan kebutuhan protein yang dianjurkan bagi penderita DM tipe 2 adalah $20 \%$ dari kebutuhan kalori harian, sehingga diperoleh kebutuhan karbohidrat makanan selingan per satu takaran saji sebanyak $10 \mathrm{~g}$. Kandungan karbohidrat dalam satu takaran saji cookies tepung beras hitam $65 \%$ sebesar $0,12 \mathrm{~g} ; 75 \%$ beras hitam sebesar $0,09 \mathrm{~g}$; $85 \%$ beras hitam sebesar $0,07 \mathrm{~g}$; dan $100 \%$ beras hitam sebesar $0,067 \mathrm{~g}$. Kandungan yang rendah berkaitan dengan kehilangan protein akibat pemanasan saat pengolahan yang dikenal dengan reaksi Maillard. Reaksi Maillard terjadi pada pemanggangan di atas suhu $115^{\circ} \mathrm{C}$, selain itu pemanggangan dengan suhu $230^{\circ} \mathrm{C}$ selama \pm 30 menit akan mengakibatkan kehilangan asam amino $15 \%{ }^{16}$, ${ }^{17}$ Pemanggangan pada pembuatan cookies dilakukan dengan suhu $150^{\circ} \mathrm{C}$ selama \pm 25 menit.

Tepung kedelai hitam mempengaruhi kadar protein cookies tepung beras hitam $(p=0,007)$. Semakin banyak kadar tepung kedelai hitam pada cookies menyebabkan kadar protein meningkat. Hal ini dikarenakan kedelai hitam memiliki kadar protein yang lebih tinggi, yaitu 35,2\% dibandingkan dengan beras hitam yang hanya memiliki kandungan protein sebesar 7,88\%. Protein berperan dalam pembentukan jaringan yang rusak dan membantu pertumbuhan sel. ${ }^{7}$ 
Konsumsi protein bernilai biologis tinggi dapat meningkatkan penyerapan dan penggunaan nitrogen, sehingga mengurangi sisa hasil metabolisme protein dalam tubuh dan tidak memperberat ginjal penderita DM Tipe $2 .{ }^{22}$ Kadar protein yang tinggi dalam pangan dapat memicu sekresi insulin, meningkatkan uptake glukosa, dan penggunaan glukosa oleh jaringan sehingga glukosa dalam darah tidak berlebih dan dapat dikendalikan. ${ }^{11}$

Perhitungan kebutuhan lemak yang dianjurkan bagi penderita DM tipe 2 adalah 25\% dari kebutuhan kalori harian, sehingga diperoleh kebutuhan lemak makanan selingan per satu takaran saji sebanyak 5,56g. Kandungan lemak dalam satu takaran saji cookies tepung beras hitam $65 \%$ sebesar 7,54g; $75 \%$ beras hitam sebesar 7,12g; $85 \%$ beras hitam sebesar 6,55g; dan $100 \%$ beras hitam sebesar $6,38 \mathrm{~g}$. Pemenuhan asupan lemak dalam satu takaran saji cookies tepung beras hitam $65 \%$ sebesar $135,6 \%$, $75 \%$ beras hitam sebesar $126,1 \%, 85 \%$ beras hitam sebesar $117,8 \%$, dan $100 \%$ beras hitam sebesar $114,7 \%$. Sumber lemak pada cookies berasal dari margarin, kuning telur, dan kedelai hitam. Berdasarkan uji lemak dan perhitungan kandungan gizi semakin tinggi tepung kedelai hitam, semakin tinggi kadar lemak pada cookies tepung beras hitam.

Asupan serat yang dianjurkan untuk penderita DM tipe 2 sebesar $25 \mathrm{~g} /$ hari. $^{12,14}$ Kandungan serat kasar dalam satu takaran saji cookies tepung beras hitam $65 \%$ sebesar 3,31g; $75 \%$ beras hitam sebesar $4,14 \mathrm{~g} ; 85 \%$ beras hitam sebesar 4,25g; dan $100 \%$ beras hitam sebesar $4,9 \mathrm{~g}$. Kadar serat kasar cookies dengan penambahan tepung kedelai hitam mengalami penurunan dibandingkan dengan kadar serat cookies tepung beras hitam 100\% . Penurunan kadar serat kasar pada cookies tepung beras hitam disebabkan karena adanya penambahan tepung kedelai hitam. Kandungan serat tak larut pada kedelai hitam yaitu sebesar 5g. ${ }^{23}$ Pada penderita DM, serat kasar akan mempertebal kerapatan dan ketebalan campuran makanan pada saluran pencernaan dan menghambat pergerakan enzim sehingga proses pencernaan menjadi lambat dan respon gula menjadi lebih rendah. ${ }^{11,15}$

\section{Tingkat Penerimaan}

Uji tingkat penerimaan dilakukan oleh 25 orang panelis dengan empat kategori pengujian yaitu warna, aroma, tekstur, dan rasa dari produk cookies. Tingkat penerimaan diperoleh dari penilaian panelis dengan skor 1-5. Dari keempat formulasi, cookies dengan $65 \%$ tepung beras hitam dan 35\% kedelai hitam merupakan formulasi terbaik. Berdasarkan analisis data dari uji tingkat penerimaan, warna yang paling disukai adalah cookies dengan 100\% tepung beras hitam karena warnanya lebih menarik jika dibandingkan dengan yang lain. Subsitusi kedelai hitam membuat panelis menganggap bahwa warna dari cookies kurang menarik.

Pada kategori aroma, cookies dengan 85\% tepung beras hitam dan $15 \%$ kedelai hitam mendapatkan skor tertinggi dibandingkan dengan formulasi yang lain. Hal ini disebabkan karena bau langu dari kedelai hitam masih agak tercium. Bau langu disebabkan oleh kerja enzim lipoksigenase yang terdapat dalam biji kedelai. aktivitas enzim lipoksigenase mudah rusak olehpanas. Untuk menghilangkan bau langu dapat dilakukan dengan cara menggunakan air panas (80$100^{\circ} \mathrm{C}$ ) pada saat penggilingan kedelai. ${ }^{27}$ Sementara itu, aroma $100 \%$ tepung beras hitam tidak disukai kemungkinan disebabkan oleh reaksi maillard yang mempengaruhi parameter aroma, dimana komponen aromatik dari cookies hilang atau berkurang selama proses perlakuan panas.

Berdasarkan uji penerimaan tekstur, dari keempat perlakuan hasil tertinggi terdapat pada cookies dengan formulasi 65\% tepung beras hitam dan $35 \%$ kedelai hitam, sedangkan yang terendah adalah cookies $100 \%$ tepung beras hitam. Tekstur dari formulasi $100 \%$ tepung beras hitam kurang renyah dibandingkan dengan cookies yang lainnya. Semakin tinggi tepung kedelai hitam yang digunakan tekstur cookies semakin renyah. Berdasarkan hasil uji semakin tinggi pemberian tepung kedelai hitam maka semakin tinggi kadar lemaknya. Tekstur dipengaruhi oleh lemak pada bahan. Cookies yang mengandung lemak yang tinggi akan mudah dipatahkan jika dibandingkan dengan cookies dengan kadar lemak yang rendah. Hal ini dikarenakan lemak akan melumaskan struktur internal pada adonan untuk mendapatkan tingkat pengembangan yang lebih baik pada saat proses pemanggangan. ${ }^{21}$

Hasil analisis data dari uji tingkat penerimaan rasa, cookies tepung beras hitam $65 \%$ dan kedelai hitam 35\% memiliki penilaian rasa yang paling tinggi di antara cookies yang lain. Menurut panelis, cookies tersebut memiliki rasa yang lebih enak dari formulasi yang lain. Meskipun memiliki penilaian rasa yang paling tinggi, cookies tersebut mendapat nilai 2,68 \pm 0,98 (netral) sehingga dibutuhkan pengembangan formulasi bahan baku supaya rasa cookies diterima di masyarakat. Rasa merupakan bagian dari organoleptik pada makanan. Penginderaan tentang rasa berasal dari indera pengecapan (lidah), yang dibagi menjadi 4 macam rasa yaitu asin, manis, pahit, dan asam. Rasa dapat ditangkap oleh indera pengecapan karena ada zat yang terlarut pada produk. ${ }^{28}$ Rendahnya nilai rasa pada tingkat penerimaan diakibatkan karena tepung beras hitam dan kedelai hitam yang tidak umum digunakan dalam pembuatan cookies dan memiliki rasa yang kurang manis karena penggunaan pemanis yang sedikit. 


\section{Indeks Glikemik dan Beban Glikemik}

Indeks glikemik merupakan suatu ukuran yang dikembangkan untuk mengklasifikasikan pangan berkarbohidrat berdasarkan pengaruh fisiologisnya terhadap kadar glukosa darah. ${ }^{18}$ Indeks glikemik merupakan angka yang diperoleh dari hasil perbandingan peningkatan glukosa darah pangan uji dengan pangan acuan. Pengujian IG menggunakan glukosa murni sebagai pangan acuan dan cookies tepung beras hitam $65 \%$ dan tepung kedelai hitam $35 \%$ sebagai pangan uji. Seluruh bahan pangan yang diuji setara dengan 50g karbohidrat yang ditentukan berdasarkan karbohidrat available. Karbohidrat available merupakan fraksi karbohidrat yang tersedia pada makanan yang mudah dicerna oleh enzim sehingga sifatnya mudah diserap dan dimetabolisme tubuh. ${ }^{19}$

Indeks glikemik pangan ditentukan berdasarkan perbandingan respon glikemik setelah mengonsumsi pangan uji dengan respon glikemik setelah mengonsumsi standar pangan acuan pada satu individu yang sama. Respon glikemik ini digambarkan dalam luas area di bawah kurva peningkatan glukosa darah. Berdasarkan respon glikemiknya pangan dibedakan menjadi 3 kelompok, yaitu pangan IG rendah $(<55)$, IG sedang $(55-70)$, dan IG tinggi $(>70) .{ }^{11}$ Berdasarkan pengelompokan tersebut, cookies tepung beras hitam $65 \%$ dan tepung kedelai hitam 35\% memiliki IG rendah sebesar $39,74 \%$. Penurunan IG dapat disebabkan oleh beberapa faktor diantaranya adalah kadar serat, protein dan lemak, serta cara pengolahan. ${ }^{11}$

Serat akan mempengaruhi IG pangan dengan cara meningkatkan viskositas, memberikan rasa kenyang yang lebih lama dan menurunkan absorpsi makronutrien sehingga akan menurunkan glukosa darah postprandial dan insulin. Bahan pangan dengan kandungan protein tinggi cenderung memiliki IG rendah karena laju pengosongan lambung menjadi lambat, sehingga pencernaan dan kenaikan glukosa darah menjadi lambat. Namun, kadar protein tidak memiliki pengaruh yang cukup besar terhadap indeks glikemik walaupun mempunyai potensi untuk menurunkan nilai IG pangan.

Pangan dengan IG rendah akan dicerna dan diubah menjadi glukosa secara bertahap dan perlahan-lahan, sehingga puncak kadar gula darah juga akan rendah, dan fluktuasi peningkatan kadar gula relatif pendek. Apabila seseorang mengkonsumsi pangan tinggi IG maka akan memicu sekresi insulin lebih banyak daripada makanan dengan IG rendah karena pangan tinggi IG mengalami fluktuasi kadar glukosa yang lebih cepat sehingga terjadi hiperglikemia. Selain itu meningkatkan hormon incretin, yaitu hormon yang berperan dalam stimulasi sekresi insulin, sehingga terjadi hiperinsulinemia yang menyebabkan resistensi insulin. ${ }^{20}$ Oleh karena itu, pada penderita DM Tipe 2 dianjurkan mengkonsumsi makanan dengan IG rendah dan mengurangi konsumsi pangan dengan IG tinggi agar kadar gula darahnya dapat dikontrol.

IG memberikan informasi mengenai kecepatan perubahan karbohidrat menjadi glukosa darah, tetapi tidak memberikan informasi mengenai banyaknya karbohidrat dan dampak pangan tertentu terhadap kadar glukosa darah. Beban glikemik (BG) dapat memberikan informasi mengenai pengaruh konsumsi pangan terhadap peningkatan kadar glukosa darah. Konsumsi makanan rendah IG bertujuan untuk mengurangi BG. BG digunakan untuk menilai dampak konsumsi karbohidrat dengan memperhitungkan IG makanan. BG berbanding lurus dengan kandungan karbohidrat makanan. Semakin rendah kandungan karbohidrat semakin rendah BG maka semakin kecil suatu makanan yang disajikan memicu peningkatan kadar glukosa darah. ${ }^{26}$

Beban glikemik makanan dikategorikan menjadi tiga, yaitu rendah $(<10)$, sedang $(11-20)$, dan tinggi $(>20)$. Cookies tepung beras hitam dan kedelai hitam memiliki beban glikemik sebesar 4,75. Beban glikemik cookies termasuk ke dalam kategori rendah.

\section{KESIMPULAN}

Cookies tepung beras hitam dan kedelai hitam memberikan pengaruh bermakna terhadap kadar serat, protein, lemak, karbohidrat, dan indeks glikemik. Pada tingkat penerimaan didapatkan hasil cookies dengan formulasi 65\% tepung beras hitam dan 35\% kedelai hitam merupakan cookies yang paling diterima oleh panelis. Tingkat penerimaan cookies tepung beras hitam dan kedelai hitam rendah pada tingkat penerimaan rasa. Nilai indeks glikemik dan beban glikemik dari formulasi tersebut yaitu 39,74 dan 4,75 yang termasuk dalam kategori rendah.

\section{SARAN}

Cookies yang direkomendasikan adalah cookies tepung beras hitam $65 \%$ dan tepung kedelai hitam $35 \%$ yang memiliki IG 39,74\% dan BG 4,75\%. Perlu dilakukan penelitian lebih lanjut tentang perbaikan formulasi bahan baku pembuatan cookies sehingga rasa cookies dapat diterima oleh masyarakat.

\section{UCAPAN TERIMA KASIH}

Puji syukur kepada Allah SWT atas segala berkah yang telah diberikan sehingga karya tulis ilmiah ini dapat diselesaikan. Penulis mengucapkan terimakasih kepada Ibu Gemala Anjani, SP., M.Si., Ph.D selaku pembimbing dan para penguji atas segala bimbingan dan saran yang telah diberikan dalam penyusunan karya tulis ini. Penulis juga mengucapkan terima kasih kepada orang tua, sahabat,dan teman-teman 
atas dukungan dan doa, lalu kepada responden serta pihak-pihak yang telah membantu pelaksanaan penelitian ini yang tidak dapat disebutkan satu persatu.

\section{DAFTAR PUSTAKA}

1. National Collaborating Centre for Chronic Conditions. Type 2 Diabetes: National Clinical Guideline for Management in Primary and Secondary Care (Update). London: Royal College of Physicians (UK); 2008.

2. Nordisk N. The Blueprint for Change Programme, Where Economics and Health Meet: Changing Diabetes in Indonesia. 2013. [cited 2016 April 8]. Available from: www.novonordisk.com.

3. International Diabetes Federation (IDF). Clinical Guidelines Task Force Global Guedelines for Type 2 Diabetes. p:72-80. 2012.

4. Wild S, Roglic G \& Green A, et al. Global Prevalence of Diabetes Diabetes Care 27:1047-1053. 2004.

5. American Diabetes Association. Diagnosis And Classification Of Diabetes Mellitus. Diabetes Care. 2011. 34.62.p9.

6. Riccardi G, et al: Role of glycemic index and Glycemic Load in the Healthy State, in Prediabtes, and in Diabetes, AM J Clin Nurt 87:269S,2008.

7. Franz MJ. Medical Nutrition Theraphy for Diabetes Mellitus and Hypoglicemia of Nondiabetic Origin. Dalam: Mahan LK, Stump SE. Krause's Food and The Nutrition Care Process $13^{\text {th }}$ edition. Elsevier: Saunders: 2012. Ha; 675-710.

8. Yang YX, Wang HW, Cui HM, Wang Y, Yu LD, Xiang $\mathrm{SX}$, et all. Glycemic index of cereals and tubers produced in China. World J Gastroenterol 2006;12(21):3430-3.

9. Sinaga Evi. Pengaruh Pemberian Susu Kedelai Terhadap Kadar Glukosa Darah Puasa Pada Wanita Prediabetes. Journal of Nutrition College, Vol.1, No.1, Tahun 2012, Hal 563-579.

10. USDA National Nutrient Database for Window Search Software. Nutrient Data Laboratory. Agriculture Research Service.

11. Rimbawan, Siagian A. Indeks Glikemik Pangan. Jakarta: Penebar Swadaya; 2004.

12. Perkumpulan Endokrinologi Indonesia. Konsensus Pengelolaan dan Pencegahan Diabetes Melitus Tipe 2 di Indonesia. Jakarta: Perkeni 2011.

13. Powell KF, Holt SHA, Miller JCB. International table of glycemic index and glycemic load. The American Journal of Clinical Nutrition. 2002. 76:5-56.

14. American Diabetes Association. Diagnosis and Classification of Diabetes Mellitus. Diabetes care. 2012 Jan [cited 2016 Nov 27];35 Suppl 1:S64-71. Available from:

http://www.pubmedcentral.nih.gov/articlerender.fcgi?a $\mathrm{rtid}=3632174 \&$ tool $=$ pm centrez\&rendertype $=$ abstract.

15. Jenkins DJA, CWC Kendall, A Marchie, AL Jenkins, LSA Augustin, DS Ludwig, et al. Type 2 diabetes and the vegetarian diet $1-4$. Am J Clin Nutr. 2003;78:610 6.

16. Muchtadi D. Teknik Evaluasi Nilai Gizi Protein. Bandung: Alfabeta; 2010. p. 5-16.
17. Cauvain S. Bread Making Improving Quality. 1st edition ed. Cambridge: Woodhead Publishing Limited; 2003.

18. Wahyuningsih R. Penatalaksanaan Diet pada Pasien. Yogyakarta: Graha Ilmu. 2013. 144-145.

19. Food and Agriculture Organization. Food EnergyMethods of Analysis and Conversion Factors. Rome: Food and Agriculture Organization of The United Nations; 2003.

20. Ludwig D. The Glycemic Index Physiological Mechanism Relating to Obesity, Diabetes, and Cardiovaskular Disease. American Med Association. 2002;287(18).

21. Matz S.A. 1992. Cookies and Crackers Technology. AUI Publishing Company Inc. London.

22. Gallagher ML. The Nutrient and Their Metabolism. In: Mahan LK, Stump SE, editors. Krause's Food and the Nutrition Care Process 13th edition. Philadelphia: WB Saunders Company; 2012. p. 32-41.

23. Badan Litbang Pertanian. Kedelai Hitam: Varietas, Kandungan Gizi, dan Prospek Bahan Baku Industri. 2012. Available from: http://www..litbang.pertanian.go.id.

24. Istiqomah A. Indeks glikemik, beban glikemik, kadar protein, serat dan tingkat kesukaan kue kering tepung garut dengan substitusi tepung kacang merah. Journal of Nutrition College. 2015:4(2):620-7.

25. Okafor, D. C; Enwereuzoh, R. O; Ibeabuchi, J. C; Uzoukwu, A. E; Alagbaoso, S. O, Udenkwo, C. Production of flour types from black bean (phaseolus vulgaris) and effect of ph and temperature on functional physico-chemical properties of the flour. European Journal of Food Science and Technology Vol.3, No.2, pp. 64-84, May 2015.

26. Gropper SS, Smith JL, Groff JL. Carbohydrates. Advanced Nutrition and Human Metabolism 5 th edition. Canada: Wadsworth;2009. p. 69-77.

27. Koswara S. Teknologi Pengolahan Kedelai Menjadikan Makanan Bermutu. First Edition. Pustaka Sinar Harapan. Jakarta. 1992. 